\title{
Impact of heat and drought stress on arable crop production in Belgium
}

\author{
A. Gobin \\ Environmental Modelling Unit, Flemish Institute for Technological Research (VITO), Belgium \\ Correspondence to: A. Gobin (anne.gobin@vito.be) \\ Received: 1 February 2012 - Revised: 14 April 2012 - Accepted: 16 April 2012 - Published: 18 June 2012
}

\begin{abstract}
Modelling approaches are needed to accelerate understanding of adverse weather impacts on crop performances and yields. The aim was to elicit biometeorological conditions that affect Belgian arable crop yield, commensurate with the scale of climatic impacts. The regional crop model REGCROP (Gobin, 2010) enabled to examine changing weather patterns in relation to the crop season and crop sensitive stages of six arable crops: winter wheat, winter barley, winter rapeseed, potato, sugar beet and maize. The sum of vapour pressure deficit during the growing season is the single best predictor of arable yields, with $R^{2}$ ranging from 0.55 for sugar beet to 0.76 for wheat. Drought and heat stress, in particular during the sensitive crop stages, occur at different times in the crop season and significantly differ between two climatic periods, 1947-1987 and 1988-2008. Though average yields have risen steadily between 1947 and 2008, there is no evidence that relative tolerance to stress has improved.
\end{abstract}

\section{Introduction}

Intensive industrial farming in Northwestern Europe is thought to have a lower vulnerability to climate change, because farmers can compensate the impacts with management and technology (Reidsma et al., 2010; Olesen et al., 2011). The inherent adaptive capacity of cropping systems to new environmental conditions and the socio-economic factors determining farmers' abilities to implement planned adaptation measures are two important components of the adaptive capacity of agriculture to climate change. Despite technological advances, weather remains a key factor in agricultural productivity, and current adaptation measures are geared mainly towards alleviating impacts of changes in mean projected climate values (Hansen et al., 2006; Falloon and Betts, 2010). In addition, the farming sector is always obliged to alter its practices or plan around the obstacles presented by ever-changing weather trends (Mechler et al., 2010).

According to IPCC's 2007 assessment (IPCC, 2007), growing seasons are expected to lengthen in higher latitudes under moderate warming conditions, and yields are expected to rise, in part because raised $\mathrm{CO}_{2}$ levels aid photosynthesis. A meta-analysis of $15 \mathrm{yr}$ of FACE experiments (Free-Air Carbon dioxide Enrichment) demonstrated that the response to elevated $\mathrm{CO}_{2}$ only slightly increased crop yields (up to $8 \%$ in wheat, none in maize) (Ainsworth and Long, 2005). Yield losses resulting from decreased soil moisture, increased heat stress or storm events may far outweigh the benefits of $\mathrm{CO}_{2}$ enrichment. The global averages in projected climate change do not account for the effects of extreme weather events. With climate change agricultural production will have to contend with unpredictable shifts in weather patterns that include an increased probability, magnitude and duration of extreme weather events (Bindi and Olesen, 2011; Maracchi et al., 2005). The perspective of rising risk exposure is exacerbated further by more limits to aid received for agricultural damage (amendments to EC Regulation 1857/2006) and an overall reduction of direct income support to farmers within the Common Agricultural Policy. These are compelling reasons for analysing extreme events and their relation with agricultural yield.

The imbalance between the short duration of an extreme event and the impact on the agroecosystem, which can be either detrimental or beneficial, has made event-focused research in agriculture difficult. The impact on plant growth depends largely on how different components of the system are affected by an intensification of the hydrologic cycle 
(Huntington, 2010). Responses of plant growth and functioning demonstrate a highly tuned sensitivity to changes in both soil and atmospheric water status. Air humidity and temperature play a major role in plant growth and regulate transpiration and assimilation through opening and closing of the stomata. Significant stomatal closure, increased leaf water use efficiency and higher carbon assimilation rates were confirmed under elevated $\mathrm{CO}_{2}$ concentrations (Wand et al., 1999). Water evaporation from leaf surfaces induces root water uptake, which in turn ensures turgor maintenance. Closing the stomata will prevent water loss but also slows down evaporative cooling. Continuing high temperatures and low humidity may therefore increase the risk of heat stress. Dryness of the atmosphere, as represented by saturation deficit, reduces dry matter production through stomatal control and leaf water potential. Upon transpiration the humidity immediately surrounding the leaves will become saturated with water vapour, such that additional water cannot evaporate and that water and nutrients are not being drawn from the root zone. High humidity may therefore cause root and nutrient deficiencies. Insights into the water regulation of growth have shown that plant parts are differentially sensitive to reduced water potential, as explained by their solute accumulation (Davies, 2007). The selection of cereals for their capacity to accumulate solutes has enhanced yields in water-scarce environments and caused changes in allometric relations.

Drought is perceived as the most significant environmental stress in agriculture worldwide, and improving yield under drought is therefore a major goal of plant breeding (Cattivelli et al., 2008). With a projected increase in drought with climate change, the breeding for drought-tolerant crops is even more emphasised (Witcombe et al., 2008). In addition to drought, temperature-induced stress causes variability in wheat yields (Semenov and Shewry, 2011; Asseng et al., 2011), corn and soybean (Schlenkera and Roberts, 2009) and other crops (e.g. Tashiro and Wardlaw, 1989; Prasad et al., 2000; Challinor et al., 2005). Drought and heat stress often occur simultaneously, but they can have very different effects on various physiological, growth, developmental and yield forming processes (Rizhysky et al., 2004; Boote et al., 2005). The majority of indices have been developed to determine long-term (months) drought or excess rain and are less suitable for short-term effects (weeks). Examples are the Palmer's Drought Severity Index (PDSI; Palmer, 1965), the Reconnaissance Drought Index (RDI; Tsakiris et al., 2007) and Standardised Precipitation Index (SPI; McKee et al., 1993). The effects of drought and heat stress on the crop depend on the occurrence of the event in relation to the crop phenological stage.

This study presents a detailed analysis of observed agricultural yields and the occurrence of heat, temperature, waterlogging and drought stress in meteorological records using the regional crop model REGCROP (Gobin, 2010). The objectives are to develop meteorological indices that represent short-term stress effects and elicit extreme events that have a substantial impact on crop yield at the regional level, commensurate with the scale of climatic impacts. The study focuses on six arable crops in Belgium: winter wheat (Triticum aestivum L.), winter barley (Hordeum vulgare L.), winter rapeseed (Brassica napus L.), maize (Zea mays L.), potato (Solanum tuberosum L.) and sugar beet (Beta vulgaris L.).

\section{Study area}

Belgium has a typically moderate Western European climate influenced by North Sea conditions. The importance of the oscillation component in rainfall series in Belgium is highlighted in several temporal clustering studies (Ntegeka and Willems, 2008; De jongh et al., 2006). The presence and occurrence of storms with single convective rain cells (associated with air-mass thunderstorms in summer) and storms with many spatially clustered rain cells (associated with cyclonic and frontal storms in winter) (Willems, 2000) explain the differences in rainfall and the effects on soil moisture during different seasons. The latter are further enhanced by an effect on temperature. In areas where soil moisture is depleted, an increase in radiation translates into a large increase in temperature, whereas in moist areas rising temperatures cause evapotranspiration rates to increase and in turn have a lowering effect on high temperatures.

The oscillation component (Ntegeka and Willems, 2008) makes it difficult to attribute the frequency and amplitude of rainfall extremes to global warming. Monthly mean temperatures, however, have already been higher during the past two decades than during any other decade before, culminating in a $1.2^{\circ} \mathrm{C}$ rise above normal (RMI, 2012; Marbaix and van Ypersele, 2004). The likelihood of extreme weather events such as severe heat waves, episodes of heavy rain and intensity and/or frequency of storms has risen significantly during the past two decades. Before 1990 a heat wave occurred about once every $8 \mathrm{yr}$, but during the last decades Belgium averages almost one heat wave per year (RMI, 2012).

The number of farm holdings in Belgium has declined by $44 \%$, whereas the total agricultural area has decreased by only $1.4 \%$, according to 1990-2007 Farm Structure Survey data (EC, 2011). Cereal production has increased by $40 \%$, and root crop production has quadrupled during the same period. The small family farm is disappearing in favour of larger agribusinesses with an intensive production due to new technologies and crop research. Since more than half of the Belgian territory is managed by the agricultural sector, extreme events such as drought and heat waves have significant impacts on agricultural systems.

\section{Methods}

The Ukkel station, located in the centre of the most productive agricultural area in Central Belgium, has the best quality meteorological time series and is maintained by the Belgian 
Table 1. Crop variables for arable crops in Belgium.

\begin{tabular}{|c|c|c|c|c|c|c|c|c|}
\hline Crop Parameter & Definition & Unit & Wheat & Barley & Potato & Sugar beet & Winter Rape & Maize \\
\hline$T_{\mathrm{b}}$ & Base temperature & ${ }^{\circ} \mathrm{C}$ & 4 & 4 & 7 & 6 & 5 & 8 \\
\hline$T_{\mathrm{O}}$ & Optimum temperature & ${ }^{\circ} \mathrm{C}$ & 18 & 18 & 21 & 20 & 17 & 22 \\
\hline$T_{\mathrm{u}}$ & Upper temperature & ${ }^{\circ} \mathrm{C}$ & 25 & 25 & 30 & 30 & 25 & 30 \\
\hline$T_{\mathrm{m}}$ & Maximum temperature & ${ }^{\circ} \mathrm{C}$ & 30 & 30 & 35 & 35 & 30 & 35 \\
\hline plant & Plant date & Date & 15 Oct & 15 Oct & 9 Apr & 9 Apr & $15 \mathrm{Sep}$ & 1 May \\
\hline harvest & Harvest date & Date & 1 Aug & $15 \mathrm{Jul}$ & $30 \mathrm{Sep}$ & $15 \mathrm{Oct}$ & $15 \mathrm{Jul}$ & 30 Sep \\
\hline Sensitive Stage** & Thermal units & ${ }^{\circ} \mathrm{C}$ & 850 & 800 & 700 & 250 & 800 & 850 \\
\hline PTU* & Potential thermal units & ${ }^{\circ} \mathrm{C}$ & 1700 & 1450 & 1350 & 1800 & 1500 & 1300 \\
\hline
\end{tabular}

* used in REGCROP; ** for most crops the sensitive stage occurs around flowering (anthesis), for potato it coincides with tuber initiation and for sugar beet the most sensitive stage is the early leaf stage.

Royal Meteorological Institute (RMI). Based on a long-term temperature analysis for Ukkel, the Belgian Royal Meteorological Institute (RMI, 2012) distinguished a first climate period (1910-1987) and a second (1988-now). All meteorological variables were compared between these two periods using ANOVA.

Historical weather records for the period 1947-2008 included rainfall $(P)$, mean/minimum/maximum/dew point temperature ( $\left.T_{\text {mean }}, T_{\min }, T_{\max }, T_{\mathrm{dew}}\right)$, solar radiation (RAD), windspeed $(u)$ and relative humidity $(\mathrm{RH})$. Vapour pressure deficit (VPD) and reference evapotranspiration $\left(\mathrm{ET}_{0}\right)$ were calculated using the FAO Penman-Monteith equation (Allen et al., 1998). Extreme values were defined as non-zero value 10th and 90th percentiles for reference evapotranspiration and rainfall, mean temperatures above $30^{\circ} \mathrm{C}$, and wind speed above $19 \mathrm{~m} \mathrm{~s}^{-1}$ (Beirlant et al., 2004). Meteorological variables were aggregated at 10-daily and monthly intervals or aggregated between planting and harvesting for the six arable crops.

Between current planting and harvesting dates, two temperature sums are evaluated: thermal unit (TU) sums between the boundary threshold temperatures as crop thermal units or $\mathrm{CTU}_{\mathrm{Tb}, \mathrm{Tu}}$, and extreme thermal unit sums above the optimal temperature (ETU). The threshold daily temperatures take into account the lag between air and soil temperatures.

$$
\begin{aligned}
\mathrm{CTU}_{\mathrm{Tb}, \mathrm{Tu}} & =\sum_{i=p}^{h} \mathrm{TU}_{t} \text { where } \mathrm{TU}_{t}=\left(T_{\mathrm{t}}-T_{\mathrm{b}}\right) \text { if } T_{\mathrm{b}} \leq T_{t} \leq T_{\mathrm{u}} \\
\mathrm{TU}_{t} & =0 \text { if } T_{t}<T_{\mathrm{b}} \text { and } \mathrm{TU}_{t}=\left(T_{\mathrm{u}}-T_{\mathrm{b}}\right) \text { if } T_{t}>T_{\mathrm{u}}
\end{aligned}
$$

$$
\begin{gathered}
\mathrm{ETU}_{>} T_{\mathrm{o}}=\sum_{i=p}^{h} \mathrm{ETU}_{t} \text { where } \mathrm{ETU}_{t}=\left(T_{\mathrm{t}}-T_{\mathrm{o}}\right) \\
\text { if } T_{t}>T_{\mathrm{o}} \text { else } \mathrm{ETU}_{t}=0
\end{gathered}
$$

Daily vapour pressure deficit (VPD) is the deficit difference between saturated and actual air moisture and is calculated according to the Penman-Monteith equation (Allen et al., 1998). VPD values below $0.45 \mathrm{kPa}$ reflect a cool and

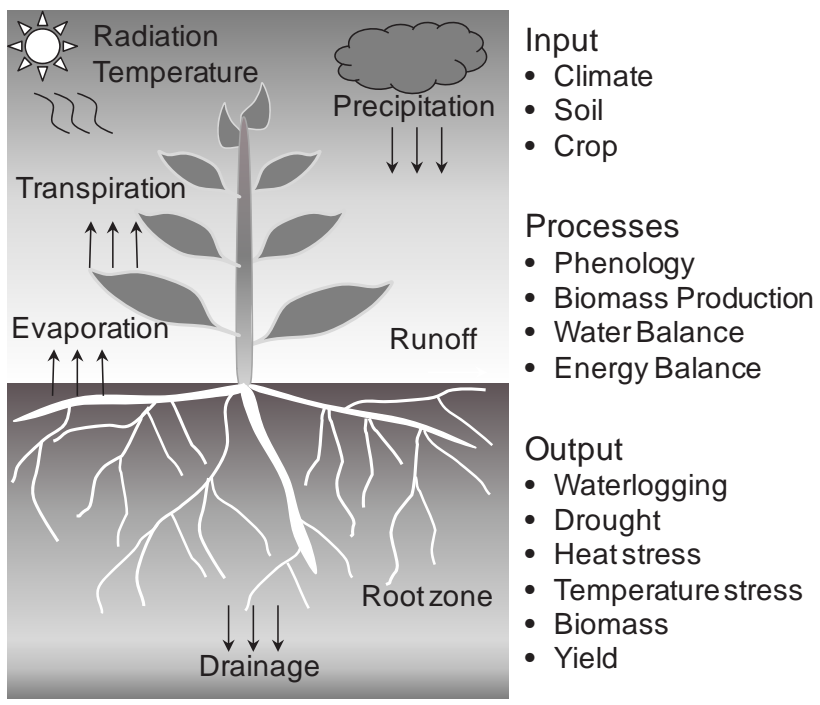

Fig. 1. Schematic diagram of REGCROP.

humid environment, values above $1.25 \mathrm{kPa}$ a hot and dry environment with values above $2 \mathrm{kPa}$ resulting in zero growth due to decreasing transpiration rates (Fletcher et al., 2007; Rodriguez and Sadras, 2007). Optimal growth is considered around $0.9-1.0 \mathrm{kPa}$. The VPD is evaluated as sums during the growing season $(\mathrm{CDU})$ and at different thresholds $\left(\mathrm{VPD}_{\mathrm{b}}=\right.$ $\left.0.25 \mathrm{kPa} ; \mathrm{VPD}_{\mathrm{o}}=1 \mathrm{kPa}\right)$. Extreme high vapour deficit sums $\left(\mathrm{EDU}_{>} \mathrm{VPDo}_{\mathrm{V}}\right)$ are calculated as VPD sums above $\mathrm{VPD}_{\mathrm{o}}(=$ $1 \mathrm{kPa})$, and extreme low vapour deficit sums $\left(\mathrm{LDU}_{<\mathrm{VPDb}}\right)$ are calculated as VPD sums below $\mathrm{VPD}_{\mathrm{b}}(=0.25 \mathrm{kPa})$.

The physical basis of the regional crop model REGCROP (Gobin, 2010) relies on quantified relationships between weather and yield at the regional scale. Phenological crop development is based on thermal time using planting dates and crop-specific upper and lower threshold temperatures (Table 1), which form the boundaries of phenological activity. The amount of solar radiation intercepted depends on the seasonal distribution of leaf area (Monteith and Moss, 1977), the development of which relies on ambient temperature and 


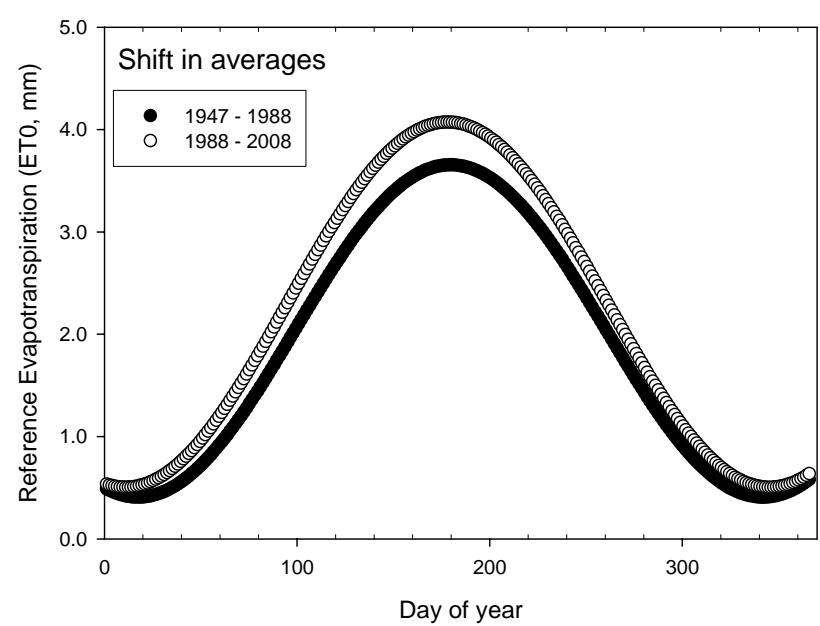

Fig. 2. A shift in average reference evapotranspiration $\left(\mathrm{ET}_{0}, \mathrm{~mm}\right)$ between two climate periods, as calculated with a sine wave model $y=y_{0}+a \times \sin \left[\frac{2 \pi \times x}{b}+c\right]$.

moisture supply in both soil and atmosphere. The water balance is a single-layer varying size bucket model, adapted from Allen et al. (1998) to incorporate effects of reduced growth conditions due to water stress (drought, water logging) or heat stress ( $T, \mathrm{VPD}$ ) on crop growth. Daily inputs and subsequent mathematical description of processes allow for establishing climate-related stress occurrences during the growing stage of the crop (Fig. 1).

Using REGCROP, the water balance is simulated from planting dates until the accumulated thermal units equal the required potential thermal units (PTU; Table 1). Biometeorological indices are subsequently based on model runs for the period 1960-2008 and include crop reduction due to temperature index (TI), vapour pressure deficit index (VPDI), waterlogging index (WLI) and drought index (DI) (Table 2). The indices are evaluated at the most sensitive stages during the growing season. For each of the six arable crops, the most sensitive periods were related to cumulative growing degree days (Table 1). For sugar beet the sensitive stages occur early during the season when warm temperatures and optimal soil moisture conditions favour early leaf stages. The most sensitive period for winter cereals is during anthesis when drought and high temperatures, from the onset of anthesis to 10 days after, cause substantial yield losses. Winter rapeseed is even more vulnerable than wheat to drought and heat stress during the flowering stage. Maize is sensitive to drought during the flowering stage. Critical periods when potato is least tolerant of water stress are at tuber initiation, which coincides with flowering. For all crops moisture conditions around germination were evaluated for a 10-day period around the time when the accumulated thermal units equal 100. Waterlogging around harvest is evaluated for a 10-day period after the potential thermal units are reached (Table 1).

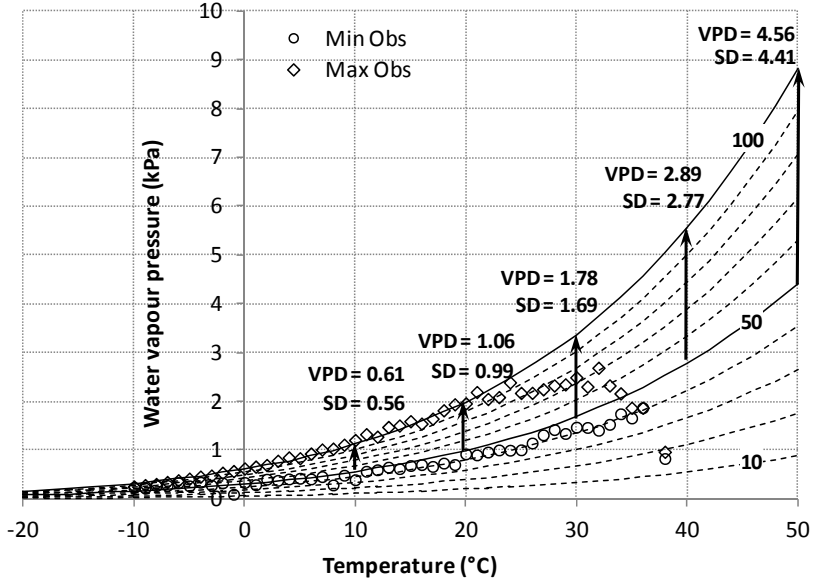

Fig. 3. Dependence of water vapour pressure, saturation deficit (SD in $\mathrm{kPa}$ ) and vapour pressure deficit (VPD in $\mathrm{kPa}$ ) on air temperatures ranging from -20 to $50^{\circ} \mathrm{C}$ and relative humidity ranging from $10 \%$ to $100 \%$. Dots represent range of daily observations of temperatures and relative humidity. The crop responds with low transpiration rates at low VPD and high rates at high VPD, provided water is available to its roots.

The approach is validated with agricultural census statistics on arable yields and production area (ADSEI, 2008). The yield data were detrended according to two different methods: linear regression and a 7-yr moving average interval. In the latter case yield differences were defined as the difference between the actual and 7-yr moving average yield. Years with yield residuals or yield differences below the 10th percentile or above the 90th percentile were defined as extreme. Multivariate correlation analysis was carried out between the annual arable crop yields and different meteorological variables and biometeorological indices. General linear modelling techniques were used to quantify the relationships between meteorological variables or indices and yield.

\section{Results}

\subsection{Meteorological observations}

Annual reference evapotranspiration linearly increased on average by $3.2 \pm 0.4 \mathrm{~mm}(p<0.001)$ per year from 1947 to $2008\left(R^{2}=0.46\right)$. Fitted annual sine waves showed a significant increase in peak amplitude from $3.654 \pm 0.0098 \mathrm{~mm}$ to $4.073 \pm 0.0148 \mathrm{~mm}$, occurring near midsummer (Fig. 2). The annual reference evapotranspiration significantly increased from $677 \pm 78 \mathrm{~mm}$ before 1988 to $787 \pm 54 \mathrm{~mm}$ for the 1988-2008 period $(p<0.001)$, with a considerable difference between seasons. The largest reference evapotranspiration increases occur in spring and summer $(39 \mathrm{~mm})$, the lowest in autumn $(14 \mathrm{~mm})$. The relative increases, however, are largest during winter $(30 \%)$ as compared to summer (14\%). 
Table 2. Biometeorological indices.

\begin{tabular}{|c|c|}
\hline Index & Biometeorological Indices \\
\hline Vapour pressure deficit Index & $\mathrm{VPDI}_{t}=\sin \left[\frac{\pi}{2}\left(1-\frac{\left(\mathrm{VPD}_{t-i}-\mathrm{VPD}_{\mathrm{o}}\right)}{\left(\mathrm{VPD}_{\mathrm{u}}-\mathrm{VPD}_{\mathrm{o}}\right)}\right)\right]$ where $\mathrm{VPD}_{\mathrm{o}}$ equals $1 \mathrm{kPa}$ and $\mathrm{VPD}_{\mathrm{u}}$ equals $2 \mathrm{kPa}$ \\
\hline Temperature Index & $\begin{array}{l}\mathrm{TI}_{t}=\sin \left(\frac{\pi}{2}\left(1-\frac{\left(T_{t-i}-T_{\mathrm{o}}\right)}{\left(T_{\mathrm{m}}-T_{\mathrm{o}}\right)}\right)\right) \text { where } T \text { is temperature; } T_{t} \text { mean temperature, } T_{\mathrm{o}} \text { and } T_{\mathrm{m}} \\
\text { are optimum and maximum temperature (Table } 1)\end{array}$ \\
\hline Drought Index & $\begin{array}{l}\mathrm{DI}_{t}=\frac{\theta_{\mathrm{CR}}-\left(\theta_{t-i}-\theta_{\mathrm{WP}}\right)}{\theta_{\mathrm{CR}}-\theta_{\mathrm{WP}}} \text { for }\left(\theta_{t-i}-\theta_{\mathrm{WP}}\right)<\theta_{\mathrm{CR}} \text { where } \theta_{t-i} \text { is water balance; higher values } \\
\text { indicate drought. For } \theta_{\mathrm{WP}} \text { see Table } 3 \text {. }\end{array}$ \\
\hline Waterlogging Index & $\begin{array}{l}\mathrm{WLI}_{t}=\frac{\left(\theta_{t-i}-\theta_{\mathrm{WP}}\right)-\theta_{\mathrm{FC}}}{\theta_{\mathrm{SAT}}-\theta_{\mathrm{FC}}} \text { for }\left(\theta_{t-i}-\theta_{\mathrm{WP}}\right)>\theta_{\mathrm{FC}} \text { where } \theta_{t-i} \text { is water balance. For } \theta_{\mathrm{WP}}, \theta_{\mathrm{FC}} \\
\text { and } \theta_{\mathrm{SAT}} \text { see Table } 3 .\end{array}$ \\
\hline
\end{tabular}

Table 3. Soil variables (after Saxton et al., 2006) as used in the REGCROP soil moisture balance. Textures are based on USDA classifications.

\begin{tabular}{lrrrrrrrl}
\hline Texture & $\begin{array}{r}\% \\
\text { Sand }\end{array}$ & $\begin{array}{r}\% \\
\text { Clay }\end{array}$ & $\begin{array}{r}\theta_{\mathrm{WP}}{ }^{*} \\
(\mathrm{vol} \%)\end{array}$ & $\begin{array}{r}\theta_{\mathrm{FC}}{ }^{*} \\
(\mathrm{vol} \%)\end{array}$ & $\begin{array}{r}\theta_{\mathrm{SAT}^{*}} \\
(\mathrm{vol} \%)\end{array}$ & $\begin{array}{r}K_{\mathrm{Sat}}{ }^{* *} \\
\left(\mathrm{~mm} \mathrm{~h}^{-1}\right)\end{array}$ & $\begin{array}{r}\mathrm{BD}^{* * *} \\
\left(\mathrm{~g} \mathrm{~cm}^{-3}\right)\end{array}$ & Crops \\
\hline Loamy sand & 82 & 6 & 5.7 & 12.1 & 45.7 & 91.3 & 1.44 & maize, potato \\
Loam & 30 & 25 & 16.4 & 31.9 & 47.2 & 9.7 & 1.40 & winter crops, sugar beet \\
\hline
\end{tabular}

$*$ moisture content at wilting point $\left(\theta_{\mathrm{WP}}\right)$, at field capacity $\left(\theta_{\mathrm{FC}}\right)$ and at saturation $\left(\theta_{\mathrm{SAT}}\right), * *$ hydraulic conductivity, $* * * \mathrm{BD}$ is bulk density.

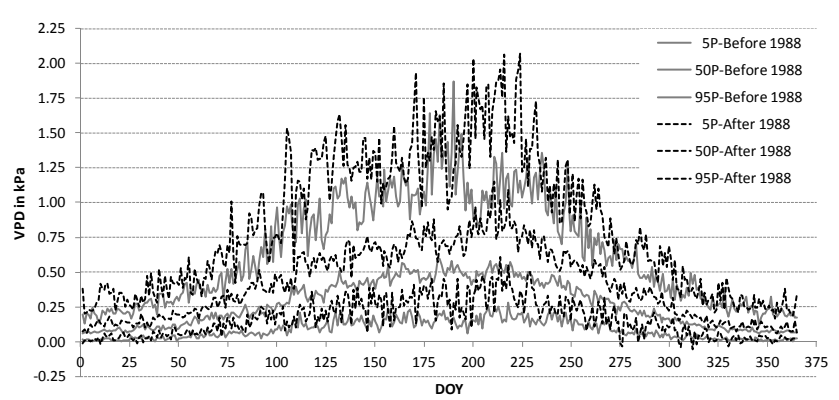

Fig. 4. Mean, 5 percentile and 95 percentile vapour pressure deficit during the year for the periods 1947-1987 and 1988-2008.

The air humidity variables have physically-based limits with basic relationships between temperature, humidity and pressure (Fig. 3); their effects on plant growth and functioning will therefore be within these limits. The saturation deficit and vapour pressure deficit increase exponentially with rising temperature at a constant relative air humidity, as provided by the example of $50 \%$ humidity (Fig. 3 ). Since potential evaporation is proportional to the vapour pressure deficit, increased reference evapotranspiration occurs at warm temperatures. The degree to which crop tissue temperatures correspond to surrounding air temperatures depends on the crop's capability to condition its microenvironment (Körner, 2006). Crops short of water close their stomata, lose their evaporative cooling potential and ultimately become susceptible to heat stress (Fig. 3).

The vapour pressure deficit (VPD) is significantly different $(p<0.001)$ between the $1947-1987$ period and the
1988-2008 period. In addition, the latter period shows a higher variability (Fig. 4). Before 1988 the 5th percentile VPD, as calculated for each year, ranged from 0 to $0.28 \mathrm{kPa}$ and the 95th percentile from 0.12 to $1.87 \mathrm{kPa}$ (Fig. 5). For each 0.1 unit increase in the 5th percentile, an increase of 0.48 times is expected for the 95th percentile of VPD. After 1988 the 5th percentile VPD ranged from 0 to $0.61 \mathrm{kPa}$ and the 95th percentile from 0.12 to $2.07 \mathrm{kPa}$. For each 0.1 unit increase in the 5th percentile, an increase of 0.31 times is expected for the 95th percentile of VPD. The differences in VPD are best captured on a higher temporal scale, since mean monthly or 10-daily VPD values may average out extreme values (Fig. 5).

\subsection{Yield observations}

Arable rainfed yields are significantly $(p<0.001)$ different between the 1947-1987 and 1988-2008 periods (Tables 4 and 5). Changes in the 10th and 90th percentiles for the 1947-1987 (M0) and 1988-2008 (M1) period show significant increases in yields (Table 4). These differences, however, are predominantly due to technological advances in the farming sector. The extent to which climate plays a role is difficult to unravel.

During the entire 1947-2008 period, yields increased at a mean $\pm \mathrm{SE}$ rate of $0.102 \pm 0.004 \mathrm{tha}^{-1} \mathrm{yr}^{-1}$ for winter wheat, $0.108 \pm 0.003 \mathrm{tha}^{-1} \mathrm{yr}^{-1}$ for winter barley, $0.418 \pm 0.020 \mathrm{tha}^{-1} \mathrm{yr}^{-1}$ for potatoes, $\quad 0.582 \pm 0.039 \mathrm{tha}^{-1} \mathrm{yr}^{-1}$ for sugar beet, $0.014 \pm 0.0005 \mathrm{tha}^{-1} \mathrm{yr}^{-1}$ for winter rapeseed and $0.137 \pm 0.009 \mathrm{tha}^{-1} \mathrm{yr}^{-1}$ for maize (Fig. 5). A high goodness of fit was obtained between Belgian arable crop 
Table 4. Linear regression $(y=a+b x)$ between arable crop yield $\left(\mathrm{tha}^{-1}\right)$ and year. Changes in the 10th and 90th percentiles for the 1947-1987 (M0) and 1988-2008 (M1) periods.

\begin{tabular}{lrrrrrrr}
\hline Crop & $a$ & $b$ & $R^{2}$ & M0-10P & M0-90P & M1-10P & M1-90P \\
\hline Wheat & -195.25 & 0.102 & 0.91 & 3.25 & 5.59 & 6.58 & 8.59 \\
Barley & -209.38 & 0.108 & 0.95 & 3.08 & 5.76 & 6.14 & 8.02 \\
Rapeseed & -25.47 & 0.014 & 0.65 & 1.88 & 3.14 & 3.04 & 3.90 \\
Potatoes & -794.37 & 0.418 & 0.83 & 22.16 & 37.42 & 36.05 & 48.18 \\
Sugar beet & -1099.77 & 0.582 & 0.70 & 34.42 & 53.63 & 55.96 & 70.25 \\
Maize & -264.050 & 0.137 & 0.88 & 3.56 & 6.75 & 7.62 & 11.97 \\
\hline
\end{tabular}

Table 5. Comparison of arable crop yield and meteorological data during the growing season for two climatic periods. p-values* $<0.05$; $* *<0.01 ; * * *<0.001 ;$ ns not significant.

\begin{tabular}{|c|c|c|c|c|c|c|c|c|c|c|c|c|c|c|c|c|c|}
\hline Crop & Period & $\begin{array}{l}\text { Yield } \\
\mathrm{tha}^{-1}\end{array}$ & & ${ }^{T_{\min }}$ & & $\begin{array}{r}T_{\max } \\
{ }^{\circ} \mathrm{C}\end{array}$ & & $\begin{array}{r}\text { VPD } \\
\mathrm{kPa}\end{array}$ & & $\begin{array}{l}\text { wind } \\
\mathrm{m} \mathrm{s}^{-1}\end{array}$ & & $\sum_{\mathrm{MJ} \mathrm{m}^{-2}}^{\sum \mathrm{rad}}$ & & $\underset{\mathrm{mm}}{\sum P}$ & & $\underset{\mathrm{mm}}{\sum \mathrm{ET}_{0}}$ & \\
\hline \multirow{2}{*}{ Winter Wheat } & 1947-1987 & $4.3 \pm 1.1$ & & $4.7 \pm 0.6$ & & $12.8 \pm 0.8$ & & $0.28 \pm 0.07$ & & $3.80 \pm 0.25$ & & $2809 \pm 420$ & & $640 \pm 130$ & & $503 \pm 56$ & \\
\hline & 1988-1908 & $7.8 \pm 0.8$ & $* * *$ & $6.0 \pm 0.7$ & $* * *$ & $13.8 \pm 0.7$ & $* * *$ & $0.41 \pm 0.04$ & $* * *$ & $3.51 \pm 0.21$ & $* * *$ & $2788 \pm 269$ & ns & $656 \pm 120$ & ns & $592 \pm 41$ & **** \\
\hline \multirow{2}{*}{ Winter Barley } & 1947-1987 & $4.2 \pm 1.1$ & & $4.2 \pm 0.6$ & & $12.2 \pm 0.8$ & & $0.27 \pm 0.07$ & & $3.84 \pm 0.26$ & & $2522 \pm 375$ & & $599 \pm 126$ & & $446 \pm 50$ & \\
\hline & 1988-1908 & $7.3 \pm 0.8$ & $* * *$ & $5.5 \pm 0.7$ & $* * *$ & $13.1 \pm 0.7$ & $* * *$ & $0.38 \pm 0.03$ & $* * *$ & $3.56 \pm 0.22$ & $* * *$ & $2479 \pm 238$ & ns & $618 \pm 116$ & ns & $521 \pm 34$ & $* * *$ \\
\hline \multirow{2}{*}{ Winter Rapeseed } & 1947-1987 & $2.4 \pm 0.5$ & & $4.7 \pm 0.6$ & & $12.7 \pm 0.7$ & & $0.27 \pm 0.07$ & & $3.78 \pm 0.25$ & & $2797 \pm 400$ & & $658 \pm 139$ & & $492 \pm 53$ & \\
\hline & 1988-1908 & $3.5 \pm 0.4$ & $* * *$ & $5.9 \pm 0.7$ & $* * *$ & $13.6 \pm 0.7$ & $* * *$ & $0.38 \pm 0.03$ & $* * *$ & $3.51 \pm 0.20$ & $* * *$ & $2733 \pm 245$ & ns & $683 \pm 130$ & ns & $576 \pm 35$ & $* * *$ \\
\hline \multirow{2}{*}{ Potatoes } & 1947-1987 & $28.8 \pm 6.0$ & & $10.0 \pm 0.6$ & & $20.7 \pm 1.1$ & & $0.50 \pm 0.15$ & & $3.35 \pm 0.22$ & & $2614 \pm 390$ & & $346 \pm 086$ & & $491 \pm 64$ & \\
\hline & 1988-1908 & $42.9 \pm 4.6$ & $* * *$ & $11.1 \pm 0.7$ & $* * *$ & $21.6 \pm 0.7$ & ns & $0.72 \pm 0.08$ & $* * *$ & $2.99 \pm 0.18$ & $* * *$ & $2578 \pm 241$ & ns & $358 \pm 067$ & ns & $556 \pm 38$ & $* * *$ \\
\hline \multirow{2}{*}{ Sugar beet } & 1947-1987 & $45.3 \pm 8.8$ & & $9.8 \pm 0.6$ & & $20.3 \pm 1.1$ & & $0.47 \pm 0.14$ & & $3.34 \pm 0.21$ & & $2889 \pm 419$ & & $407 \pm 091$ & & $538 \pm 68$ & \\
\hline & $1988-1908$ & $63.7 \pm 5.7$ & $* * *$ & $10.9 \pm 0.7$ & $* * *$ & $21.0 \pm 0.7$ & ns & $0.67 \pm 0.07$ & $* * *$ & $3.01 \pm 0.19$ & $* * *$ & $2831 \pm 265$ & ns & $424 \pm 079$ & ns & $610 \pm 43$ & **** \\
\hline \multirow{2}{*}{ Grain Maize } & 1947-1987 & $5.1 \pm 1.3$ & & $10.7 \pm 0.6$ & & $21.4 \pm 1.2$ & & $0.50 \pm 0.15$ & & $3.28 \pm 0.24$ & & $2451 \pm 353$ & & $339 \pm 080$ & & $465 \pm 61$ & \\
\hline & 1988-1908 & $9.9 \pm 1.6$ & $* * *$ & $11.8 \pm 0.7$ & $* * *$ & $22.1 \pm 1.0$ & ns & $0.72 \pm 0.09$ & $* * *$ & $2.95 \pm 0.20$ & $* * *$ & $2410 \pm 246$ & ns & $350 \pm 074$ & ns & $525 \pm 42$ & **** \\
\hline
\end{tabular}

yields and time, with $R^{2}$ ranging from 0.65 for winter rapeseed to 0.95 for winter wheat (Table 4, Fig. 5). There was no correlation between yield and area. In the case of maize, areas have spectacularly increased since the 1990s. The rate of yield increase seems to slow down during the last few years of data records; this trend is to be confirmed as more recent years will be added.

Extreme yield values were identified on the basis of the residuals from the linear regression analysis and the yield gap analysis (Fig. 5). Yield residuals and deviations from the 7-yr moving average are on average but not significantly negative during the 1947-1987 period and positive during the 19882008 period, but this is not significant. The mean residuals are below $100 \mathrm{~kg}$ apart from potato and sugar beet where the mean residual equals $243 \mathrm{~kg}$ and $233 \mathrm{~kg}$, respectively. The deviations from the 7-yr moving average are below $20 \mathrm{~kg}$ for cereals, below $5 \mathrm{~kg}$ for maize and rapeseed and below 50 for potato and sugar beet.

\subsection{Biometeorological observations and indices during the growing season}

Temperatures during the growing season show significant differences between the mean of the minimum temperature $\left(T_{\min }\right)$ for the two climatic periods at the $99.9 \%$ confidence level (Table 5). For the winter crops an increase of $1.3^{\circ} \mathrm{C}$ in $T_{\min }$ is observed and a $1.1{ }^{\circ} \mathrm{C}$ rise for the summer crops. The mean of the maximum temperature during the growing season differed significantly $(p>0.001)$ for winter crops but not for summer crops. The average daily VPD during the growing season is significantly lower before 1988 than after 1988 ( $p<0.001$; Table 5). Both the VPD and mean wind speed increased significantly during the last two decades, resulting in a significant difference in total reference evapotranspiration during the growing season. The sum of rainfall and the sum of radiation, however, did not significantly differ between the growing seasons during the two climatic periods; although, the total rainfall is higher during the last decades but the total radiation is lower.

The crop thermal units (CTU) are significantly higher ( $p<0.001)$ during the $1988-2008$ period as compared to 1947-1987 (Table 6) between fixed planting and harvesting dates (Table 1). The potential thermal units at maturity (Table 1$)$ shift significantly $(p<0.001)$ with, on average, 18 days for winter cereals, 16 days for rapeseed, 19 days for potato, 25 days for maize and 30 days for sugar beet, allowing for earlier harvests during the last two decades (Fig. 7). The sum of temperatures above the optimum crop temperature (ETU in Table 6) increased significantly with an average of 35 degree sums for winter wheat and 13 for maize. The crop vapour deficit sums (CDU in Table 6) differ between the two climatic periods at the $99.9 \%$ confidence level with a decrease in the standard deviation, indicating a lower dispersion from the average. The sum of VPD values below 

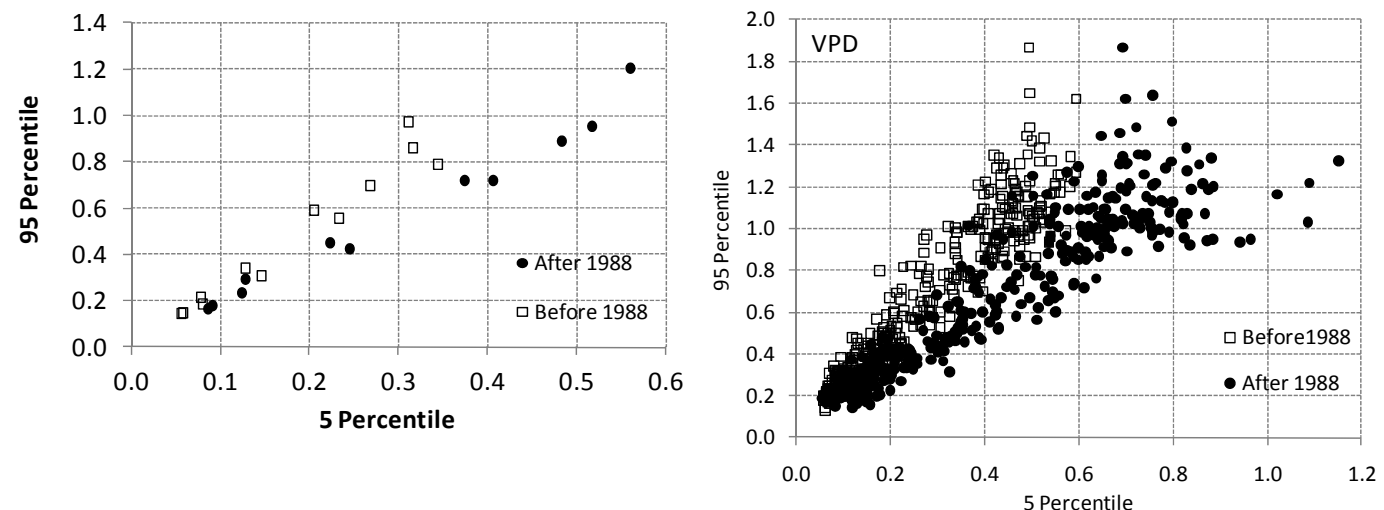

Fig. 5. Change in range of monthly (left) and daily (right) vapour pressure deficit (in kPa) between the periods 1947-1987 and 1988-2008.
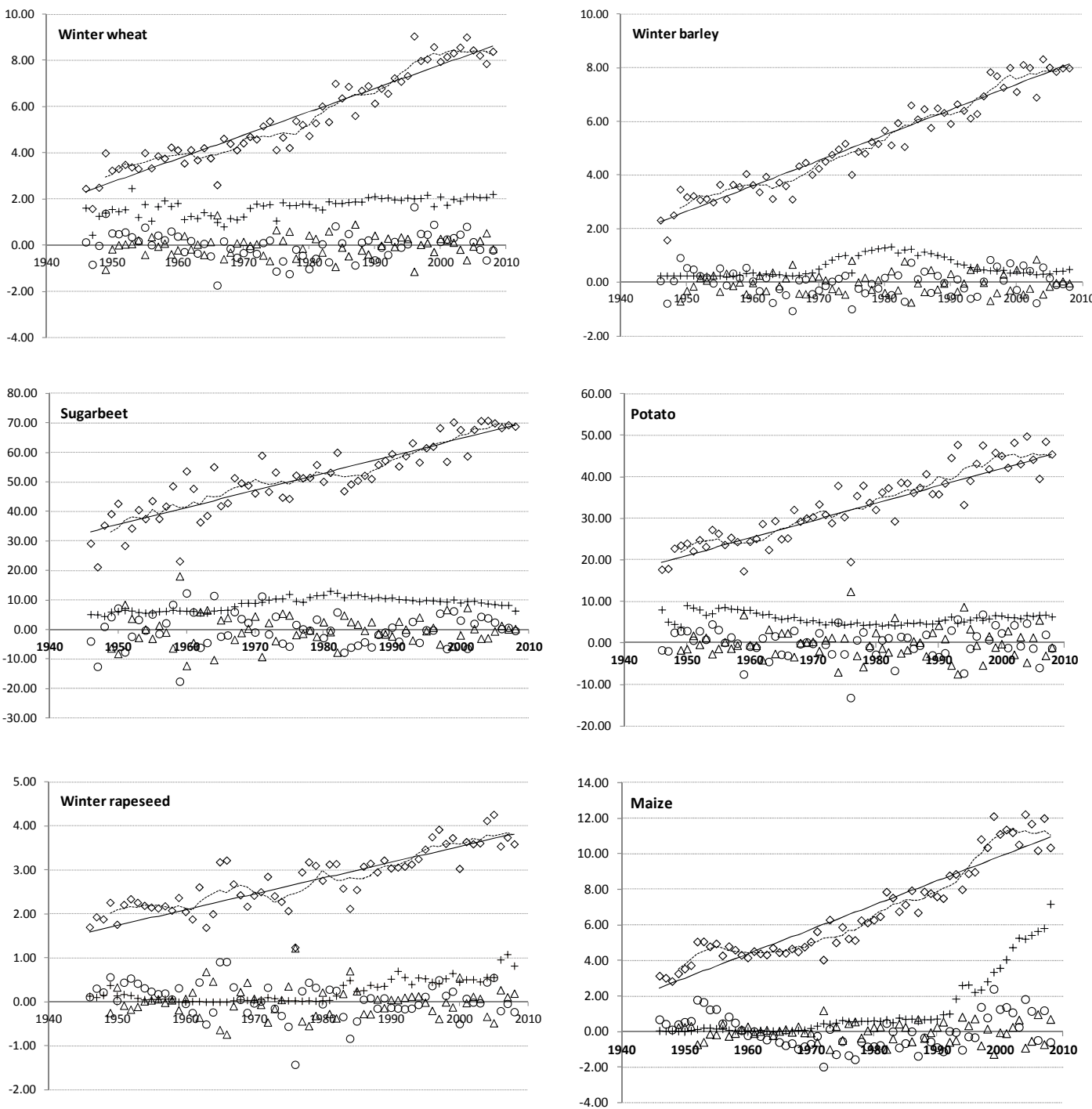

Fig. 6. Observed and detrended yields of six Belgian arable crops for the period 1946-2008. Symbols: $\diamond$ yield in tha $^{-1},-$ linear regression line, o residuals, $-7 \mathrm{yr}$ moving average, $\Delta$ difference with moving average, + area in 100000 ha for winter cereals, in 10000 for other crops. 


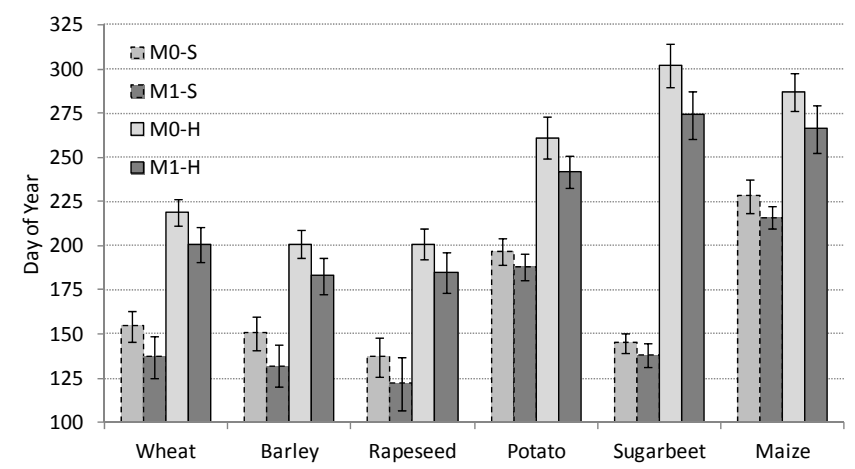

Fig. 7. Difference between the occurrence of sensitive stages (S) and harvesting $(\mathrm{H})$, as determined with cumulative thermal units between the periods 1947-1987 (M0) and 1988-2008 (M1) with fixed planting dates (Table 1). Error bars reflect standard deviation.

$0.25 \mathrm{kPa}$ (LDU in Table 6) during the season declines during the last two decades, particularly for the summer crops. The sum of VPD values above $1 \mathrm{kPa}$ (EDU in Table 6) doubles or even triples in the case of winter wheat.

Heat and moisture stress were evaluated for the sensitive stages, including germination and harvesting, calculated as thermal unit sums from planting (Table 1). All sensitive stages occur significantly earlier in the season $(p<0.001$; Fig. 7), with the exception of germination of the three winter crops. Earlier germination of summer crops is significant at the 0.05 level. Temperature stress at germination does not pose a significant problem for winter crops; summer crops are increasingly confronted with stress, owing to $10 \%$ higher maximum temperatures at germination when current planting dates are maintained. Drought is an increasing problem at germination and during the early stages of summer crops, as reflected in a $10-15 \%$ increase in 95 th percentile DI, particularly for maize when the 50th percentile number of dry days can increase from 4.5 to 7.3 during germination. Drought is absent during the germination of winter crops. The 95th percentile days, when waterlogging occurs, decrease by $29 \%$ for winter cereals and $43 \%$ for rapeseed. The magnitude (as presented by the 95th percentile water logging index) decreases by $40 \%$ at rapeseed germination. The 95 th percentile VPD values during the different sensitive stages of all arable crops are, on average, between $32.2 \%$ (rapeseed) and $89.3 \%$ (maize) higher during the second climatic period, indicating a higher risk of atmospheric moisture deficit (Fig. 8). The corresponding index VPDI indicates that this could be a problem for winter crops and sugar beets. Despite the earlier occurrence of the sensitive stage in the growing season, the 95th percentile values for $T_{\text {mean }}, T_{\max }$ and TI are, on average, higher during the second climatic period. The differences in TI are significant for barley $(p<0.05)$, rapeseed $(p<0.05)$, sugar beet $(p<0.05)$ and maize $(p<0.001)$. For sugar beet and maize the differences in 95th percentile $T_{\max }$ during the sensitive stage are significant at the 0.05 level (Fig. 8). The soil moisture deficit around the sensitive stages decreases both in magnitude and frequency in the case of the three winter crops when atmospheric drought may be compensated for with soil moisture (Fig. 8). For the three summer crops, the risk of drought spells during the sensitive stages increases and may be aggravated by atmospheric moisture deficits and heat stress.

The soil workability is evaluated by the frequency and magnitude of waterlogging around planting and harvesting (PTU, Table 1). The number of waterlogged days at planting declines during the 1988-2008 period, but this is only significant $(p<0.05)$ for sugar beet and potato (Fig. 9). The 95th percentile waterlogging index at planting declines with $8 \%$ for winter cereals, $10 \%$ for sugar beet, $15 \%$ for potato, $18 \%$ for rapeseed and $45 \%$ for maize. The 95th percentile number of waterlogged days at harvest decreases with $10 \%$ for maize, $55 \%$ for sugar beet, $65 \%$ for rapeseed and $100 \%$ for winter cereals (no risk), whereas an increase of $17 \%$ was observed for potato (Fig. 9). The 95th percentile waterlogging index at harvest reduces with $68 \%$ for maize, $43 \%$ for sugar beet, $42 \%$ for rapeseed and only $8 \%$ for potato.

\subsection{Statistical relationships}

The sum of vapour pressure deficit during the growing season is the single best predictor of arable yields at the national scale, with $R^{2}$ ranging from 0.55 for sugar beet, 0.59 for rapeseed, 0.60 for potato, 0.62 for maize, 0.66 for barley and 0.76 for wheat (Fig. 10). For winter cereals and maize, the best goodness of fit was obtained with the sum of vapour pressure deficit during the growing season $\left(\sum V P D\right)$. For all other arable crops, a better fit was found with the sum of $\mathrm{VPD} \leq 1 \mathrm{kPa}$ during the growing season $\left(\sum \mathrm{VPD}_{\leq 1} \mathrm{kPa}\right)$ (Fig. 10). The rate of increase is $67 \mathrm{~kg}$ for winter cereals and $85 \mathrm{~kg}$ for maize per unit increase in $\sum$ VPD. For each unit increase in $\sum \mathrm{VPD}_{\leq 1} \mathrm{kPa}$, an increase is expected of $35 \mathrm{~kg}$ for rapeseed, $382 \mathrm{~kg}$ for potato and $402 \mathrm{~kg}$ for sugar beet. During the 1947-2008 period a one tenth degree increase in average minimum temperature during the growing season corresponds to an increase of $242 \mathrm{~kg} \mathrm{ha}^{-1}$ maize $\left(R^{2}=0.54\right), 998 \mathrm{~kg} \mathrm{ha}^{-1}$ sugar beet $\left(R^{2}=0.54\right)$, $621 \mathrm{~kg} \mathrm{ha}^{-1}$ potato $\left(R^{2}=0.38\right), 124 \mathrm{~kg} \mathrm{ha}^{-1}$ wheat $\left(R^{2}=\right.$ $0.34), 110 \mathrm{~kg} \mathrm{ha}^{-1}$ barley $\left(R^{2}=0.34\right)$ and $41 \mathrm{~kg} \mathrm{ha}^{-1}$ rapeseed $\left(R^{2}=0.31\right)$. Significant relationships were found between yield and thermal heat unit sums. CTU accounts for $44 \%$ of the yield variation in sugar beet, $35 \%$ in maize, $33 \%$ in wheat, $28 \%$ in barley, $28 \%$ in rapeseed and $26 \%$ in potato. Wind speed has a strong negative relationship with yield, with $R^{2}$ equal to 0.48 for sugar beet, 0.46 for wheat, 0.45 for potato, 0.42 for barley, 0.39 for rapeseed and 0.35 for maize. Since VPD, temperature and wind speed are important variables that relate to reference evapotranspiration, significant relationships between yield and reference evapotranspiration sums during the growing season were obtained. The 
Table 6. Comparison of arable crop yield and biometeorological indices during the growing season for two climatic periods. $p$-values $*<0.05 ; * *<0.01 ; * * *<0.001 ;$ ns not significant.

\begin{tabular}{|c|c|c|c|c|c|c|c|c|c|c|c|}
\hline Crop & Period & $\begin{array}{l}\mathrm{CTU} \\
{ }^{\circ} \mathrm{C}\end{array}$ & & $\begin{array}{l}\text { ETU } \\
{ }^{\circ} \mathrm{C}\end{array}$ & & $\begin{array}{r}\mathrm{CDU} \\
\mathrm{kPa}\end{array}$ & & $\begin{array}{r}\mathrm{LDU}(<0.25) \\
\mathrm{kPa}\end{array}$ & & $\begin{array}{r}\mathrm{EDU}(>1) \\
\mathrm{kPa}\end{array}$ & \\
\hline Winter Wheat & $\begin{array}{l}1947-1987 \\
1988-1908\end{array}$ & $\begin{array}{l}1621 \pm 117 \\
1874 \pm 140\end{array}$ & $* * *$ & $\begin{array}{l}61 \pm 36 \\
96 \pm 43\end{array}$ & $* *$ & $\begin{array}{r}82.8 \pm 20.6 \\
119.6 \pm 11.9\end{array}$ & $* * *$ & $\begin{array}{l}19.7 \pm 2.4 \\
16.9 \pm 2.2\end{array}$ & $* * *$ & $\begin{array}{l}10.5 \pm 13.0 \\
30.0 \pm 12.8\end{array}$ & $* * *$ \\
\hline Winter Barley & $\begin{array}{l}1947-1987 \\
1988-1908\end{array}$ & $\begin{array}{l}1386 \pm 111 \\
1610 \pm 140\end{array}$ & $* * *$ & $\begin{array}{l}43 \pm 32 \\
59 \pm 26\end{array}$ & $*$ & $\begin{array}{r}73.6 \pm 18.5 \\
104.0 \pm 09.5\end{array}$ & $* * *$ & $\begin{array}{l}19.3 \pm 2.3 \\
16.8 \pm 2.1\end{array}$ & $* * *$ & $\begin{array}{l}09.2 \pm 12.0 \\
21.7 \pm 09.4\end{array}$ & $* * *$ \\
\hline Winter Rapeseed & $\begin{array}{l}1947-1987 \\
1988-1908\end{array}$ & $\begin{array}{l}1448 \pm 112 \\
1660 \pm 141\end{array}$ & $* * *$ & $\begin{array}{l}70 \pm 40 \\
94 \pm 29\end{array}$ & $*$ & $\begin{array}{r}82.4 \pm 20.5 \\
116.6 \pm 10.0\end{array}$ & $* * *$ & $\begin{array}{l}21.5 \pm 2.7 \\
17.9 \pm 2.3\end{array}$ & $* * *$ & $\begin{array}{l}09.4 \pm 12.0 \\
22.3 \pm 09.5\end{array}$ & $* * *$ \\
\hline Potatoes & $\begin{array}{l}1947-1987 \\
1988-1908\end{array}$ & $\begin{array}{l}1328 \pm 125 \\
1483 \pm 090\end{array}$ & $* * *$ & $\begin{array}{l}24 \pm 23 \\
45 \pm 28\end{array}$ & $* *$ & $\begin{array}{r}79.2 \pm 23.4 \\
113.7 \pm 12.2\end{array}$ & $* * *$ & $\begin{array}{l}5.1 \pm 3.1 \\
1.8 \pm 0.7\end{array}$ & $* * *$ & $\begin{array}{l}14.5 \pm 17.8 \\
40.7 \pm 16.0\end{array}$ & $* * *$ \\
\hline Sugar beet & $\begin{array}{l}1947-1987 \\
1988-1908\end{array}$ & $\begin{array}{l}1710 \pm 144 \\
1872 \pm 109\end{array}$ & $* * *$ & $\begin{array}{l}41 \pm 33 \\
70 \pm 38\end{array}$ & $* *$ & $\begin{array}{r}88.3 \pm 25.6 \\
126.2 \pm 13.8\end{array}$ & $* * *$ & $\begin{array}{l}7.3 \pm 3.8 \\
2.9 \pm 1.0\end{array}$ & $* * *$ & $\begin{array}{l}14.8 \pm 18.0 \\
41.3 \pm 16.8\end{array}$ & $* * *$ \\
\hline Maize & $\begin{array}{l}1947-1987 \\
1988-1908\end{array}$ & $\begin{array}{l}1221 \pm 126 \\
1356 \pm 106\end{array}$ & $* * *$ & $\begin{array}{l}14 \pm 17 \\
27 \pm 20\end{array}$ & $* * *$ & $\begin{array}{r}76.0 \pm 22.9 \\
108.9 \pm 13.6\end{array}$ & $* * *$ & $\begin{array}{l}4.8 \pm 3.0 \\
1.7 \pm 0.9\end{array}$ & $* * *$ & $\begin{array}{l}13.9 \pm 17.7 \\
38.7 \pm 17.1\end{array}$ & $* * *$ \\
\hline
\end{tabular}
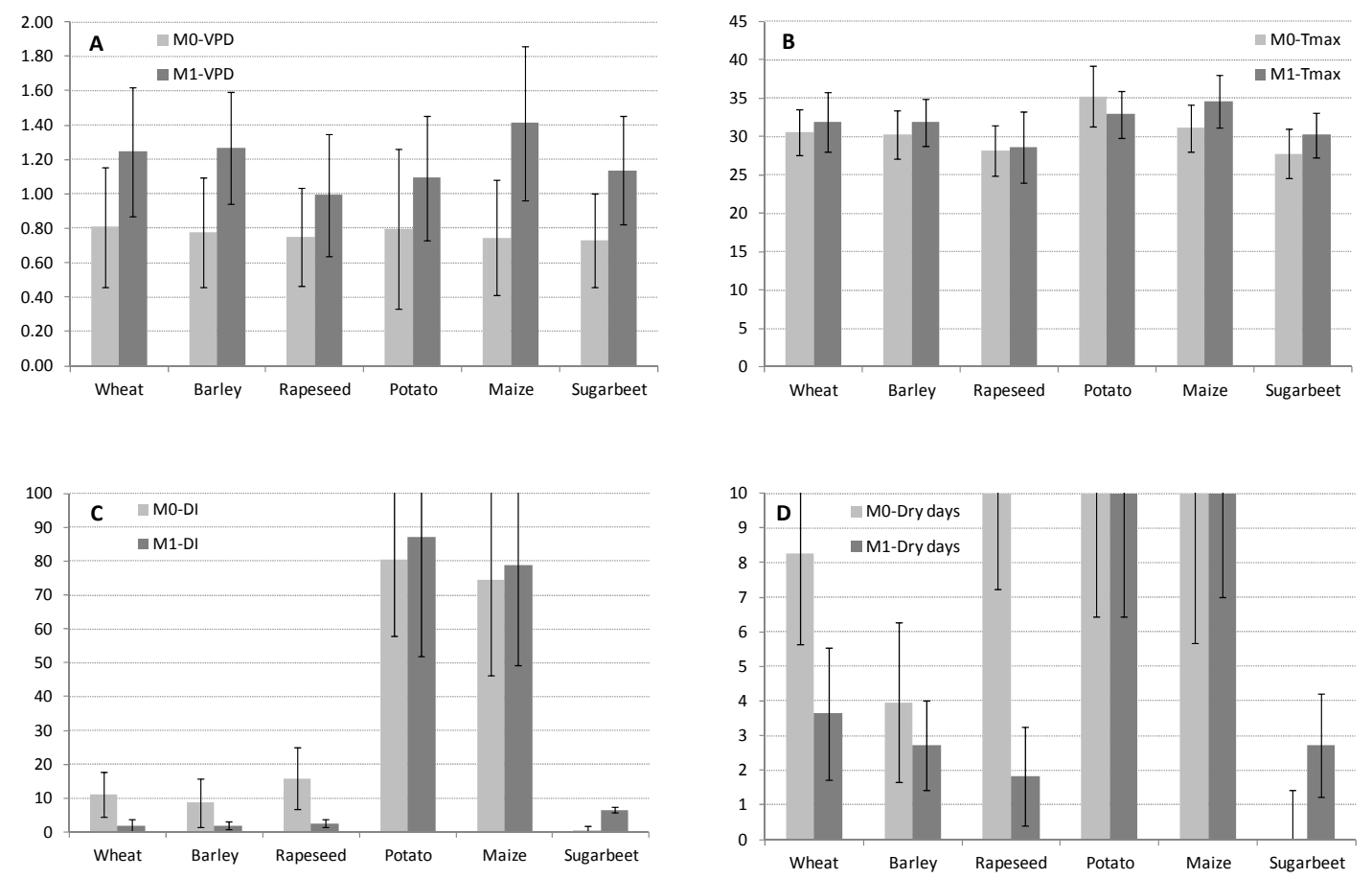

Fig. 8. Biometeorological indices during 10 days around the sensitive stages of six arable crops in Belgium (as defined in Table 1) averaged between the periods 1947-1987 (M0) and 1988-2008 (M1). (A) atmospheric moisture as 95th percentile VPD (kPa), (B) heat as 95th percentile $T_{\max }\left({ }^{\circ} \mathrm{C}\right),(\mathbf{C})$ soil moisture as 95 th percentile drought index $(\%)$, (D) frequency of drought in 95th percentile days (number of days). Error bars reflect standard deviation.

sum of radiation and the sum of rainfall during the growing season, however, did not result in significant relationships.

The sums of extreme meteorological variables during the growing season help explain arable yield variability. LDU relates negatively while EDU positively to arable yields. LDU explains the yield variation of winter crops for $31 \%$ (rapeseed), $33 \%$ (barley) and $36 \%$ (wheat). For the summer crops
LDU explains a higher portion of the variability, i.e. $47 \%$ for maize, $50 \%$ for sugar beet and $52 \%$ for potato. EDU explains $35 \%$ of potato yield variability, $45 \%$ of rapeseed, $48 \%$ of sugar beet, $50 \%$ of maize, $54 \%$ of barley and $59 \%$ of wheat yield variability. ETU relates positively to yield but with less power of explaining the yield variation; $R^{2}$ values range from 0.13 for potato to 0.23 for wheat. ETU is weakly 

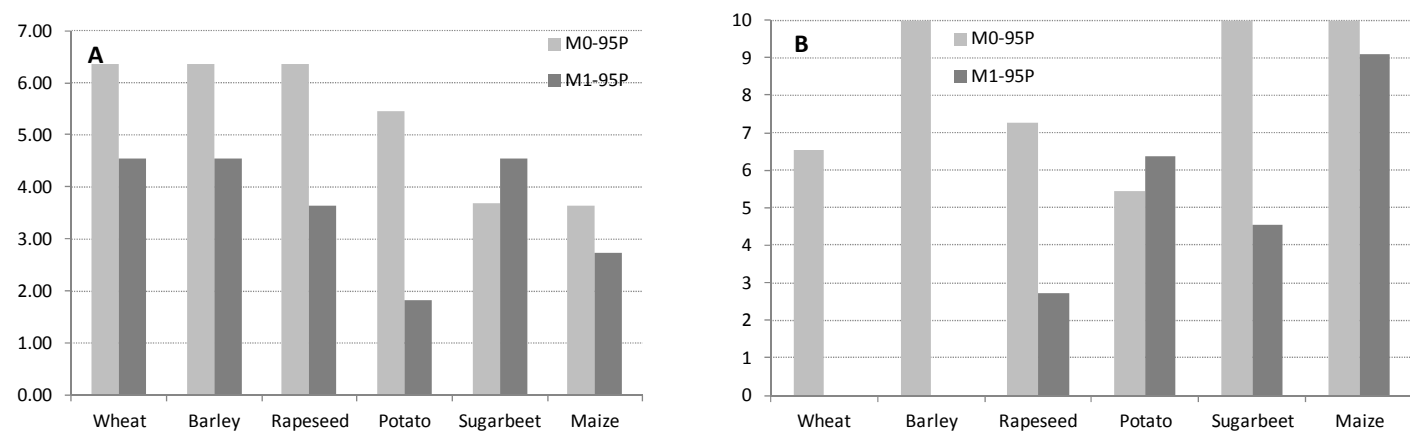

Fig. 9. Frequency of waterlogging in 95th percentile days during planting (A) and harvesting (B).
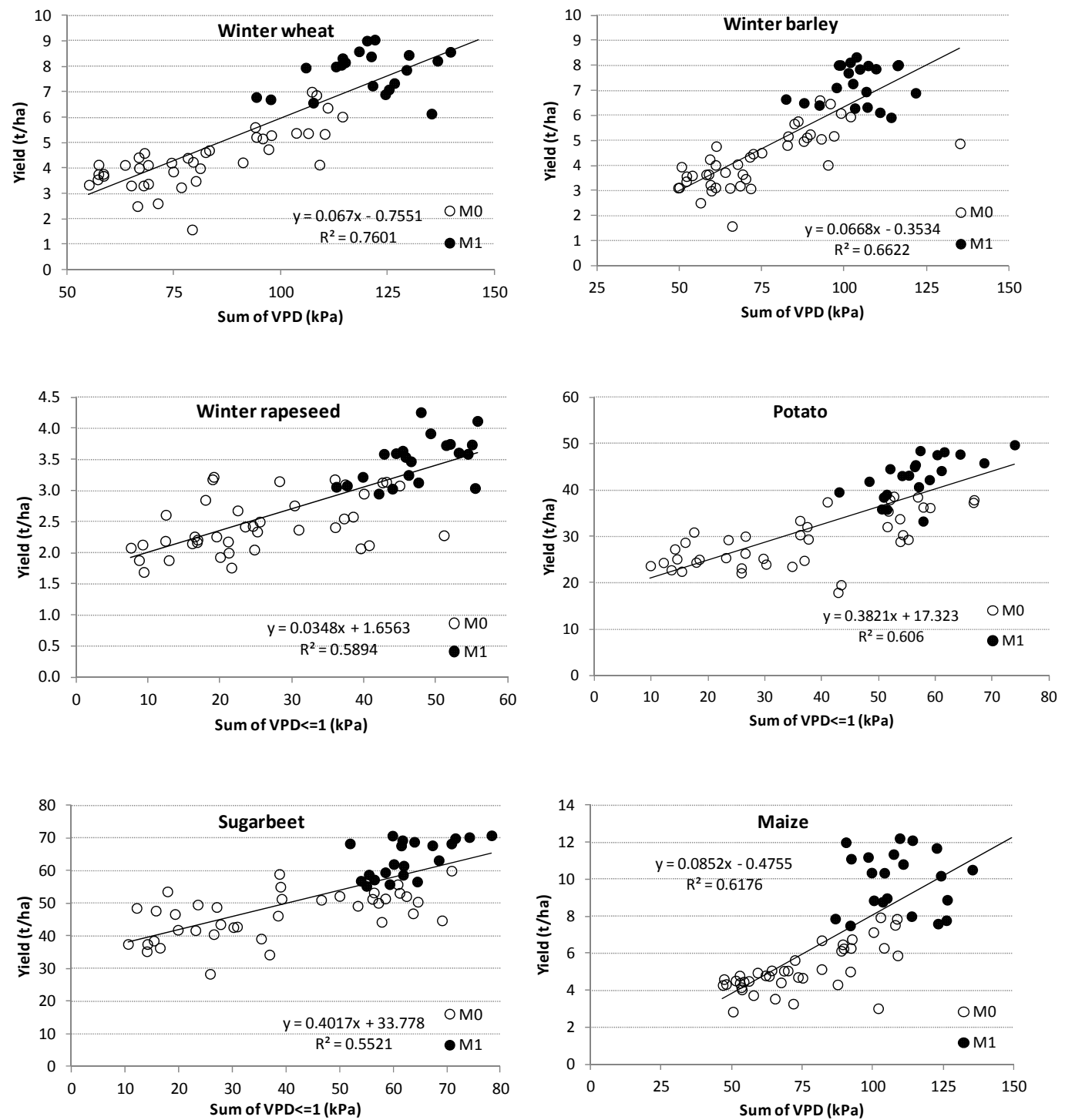

Fig. 10. Relationship between yield and sum of VPD for winter cereals and sum of VPD $<=1$ for other arable crops during the growing season. 
related to arable yield. While average yields have risen continuously, there is no evidence that relative tolerance to adverse atmospheric moisture contents and temperatures has improved between 1947 and 2008. Winter crop yield residuals relate very weakly: $R^{2}$ between 0.1 and 0.2 to precipitation sums (negative) and to radiation sums (positive) during the growing season. The variation in potato yield residuals can be accounted for by ETU for $24 \%$; likewise, radiation sums explain $31 \%$ of the variation in maize yield residuals.

\section{Conclusions}

Drought and heat stress are among the two most important environmental factors influencing crop growth and yield. The meteorological impacts on crop growth are twofold, owing to the sensitive stages occurring earlier during the growing season and to the changes in weather patterns with climate change. Since crop development is driven by thermal time, crops matured earlier during the warmer 1988-2008 period than during the 1947-1987 period. The sum of vapour pressure deficit during the growing season is the single best predictor of arable yields at the national scale. Water and heat stress, in particular during the sensitive crop stages, occur at different times in the crop season. Soil water deficit increases towards harvesting, such that earlier maturing winter crops may avoid drought stress that occurs in late spring and summer. Summer crops may benefit from earlier planting dates and subsequent beneficial moisture conditions during early canopy development, but will suffer from increased drought and heat stress during crop maturity. Though average yields have risen continuously between 1947 and 2008, there is no evidence that relative tolerance to adverse weather conditions such as atmospheric moisture deficit and temperature extremes has improved.

A modelling approach to the analysis of marked differences between the years and climatic periods contributes to an increased understanding of meteorological impacts on arable crop yield and development. Against the projected $\mathrm{CO}_{2}$ fertilisation effect under climate change must be weighted for the impact of adverse weather conditions, thresholds and crop responses. A sharp increase in extreme heat and drought is projected by the end of the century, with the potential to significantly reduce yields under current technologies.

Acknowledgements. The author wishes to thank A. M. Tarquis, N. R. Dalezios, R. Moratiel and an anonymous referee for reviewing and improving the manuscript.

Edited by: A. M. Tarquis

Reviewed by: N. R. Dalezios, R. Moratiel, and another anonymous referee

\section{References}

ADSEI: Landbouw: statistieken en cijfers, available at: http://statbel.fgov.be/nl/statistieken/cijfers/economie/landbouw/ index.jsp, 2008.

Ainsworth, E. and Long, S.: What have we learned from 15 years of Free-Air $\mathrm{CO}_{2}$ Enrichment (FACE)?, New Phythologist, 165, 351-371, 2005.

Allen, R. G., Pereira, L. S., Raes, D., and Smith, M.: Crop evapotranspiration: Guidelines for computing crop requirements, FAO, Irrigation and Drainage Paper No. 56, FAO, Rome, Italy, 300 pp., 1998.

Asseng, S., Foster, I., and Turner, N. C.: The impact of temperature variability on wheat yields, Glob. Change Biol., 17, 997-1012, 2011.

Beirlant, J., Goegebeur, Y., Segers, J., and Teugels, J.: Statistics of Extremes: Theory and Applications, John Wiley \& Sons, Chapter $1,1-44,2004$.

Bindi, M. and Olesen, J.: The responses of agriculture in Europe to climate change, Reg. Environ. Change, 11, S151-S158, 2011.

Boote, K. J., Allen, L. H., Prasad, P. V. V., Baker, J. T., Gesch, R. W., Synder, A. M., Pan, D., and Thomas, J. M. G.: Elevated temperature and $\mathrm{CO}_{2}$ impacts on pollination, reproductive growth and yield of several globally important crops, J. Agric. Meteorol., 60, 469-474, 2005.

Cattivellia, L., Rizza, F., Badeck, F.-W., Mazzucotelli, E., Mastrangelo, A. M., Francia, E., Marè, C., Tondellia, A., and Stanca, M.: Drought tolerance improvement in crop plants: An integrated view from breeding to genomics, Drought tolerance improvement in crop plants: An integrated view from breeding to genomics, Field Crops Res., 105, 1-14, 2008.

Challinor, A. J., Wheeler, T. W., and Slingo, M.: Simulation of the impact of high temperature stress on the yield of an annual crop, Agr. Forest Meteorol., 135, 180-189, 2005.

Davies, W. J.: Responses of plant growth and functioning to changes in water supply in a changing climate, in: Plant Growth and Climate Change, edited by: Morison, J. I. L. and Morecroft, D. M., Blackwell Publishing, Oxford, 96-114, 2007.

De Jongh, I. L. M., Verhoest, N. E. C., and De Troch, F. P.: Analysis of a 105-year time series of precipitation observed at Uccle, Belgium, Int. J. Climatol., 26, 2023-2039, 2006.

EC: Farm structure survey statistics on agricultural holdings in the EU, available at: http://epp.eurostat.ec.europa.eu/portal/page/ portal/agriculture/data/database, 2011.

Falloon, P. and Betts, R.: Climate impacts on European agriculture and water management in the context of adaptation and mitigation - The importance of and integrated approach, Science Total Environ., 408, 5667-5687, 2010.

Fletcher, A. L., Sinclair, T. R., Allen, L. H. J. R.: Transpiration responses to vapor pressure deficit in well watered "slow-wilting" and commercial soybean, Environ. Experimental Botany, 61, 145-151, 2007.

Gobin, A.: Modelling climate impacts on arable yields in Belgium, Clim. Res., 44, 55-68, 2010.

Hansen, J. W., Challinor, A., Ines, A. V. M., Wheeler, T., and Moron, V.: Translating climate forecasts into agricultural terms: advances and challenges, Clim. Res., 33, 27-41, 2006.

Huntington, T. G.: Climate warming-induced intensification of the hydrologic cycle: an assessment of the published record and potential impacts on agriculture, Adv. Agron., 109, 1-53, 2010. 
IPCC: Climate Change 2007: Impacts, Adaptation and Vulnerability, Contribution of Working Group II to the Fourth Assessment Report of the Intergovernmental Panel on Climate Change, Annex I., edited by: Parry, M. L., Canziani, O. F., Palutikof, J. P., van der Linden, P. J., and Hanson, C. E., Cambridge University Press, Cambridge, UK, 976 pp., 2007.

Körner, C.: Significance of temperature in plant life, in: Plant growth and climate change, edited by: Morison, J. I. L. and Morecroft, M. D., 2nd Edn., Blackwell Publishing, Oxford, UK, 4869, 2006.

Maracchi, G., Sirotenko, O., and Bindi, M.: Impacts of present and future climate variability on agriculture and forestry in the temperate regions: Europe, Climatic Change, 70, 117-135, 2005.

Marbaix, P. and van Ypersele, J. P.: Impacts of climate change in Belgium, Brussels, Greenpeace, 2004.

McKee, T. B., Doeskens, N. J., and Kleist, J.: The relationship of drought frequency and duration to time scales, 8th Conference on Applied Climatology, 17-22 January, Anaheim, CA, 179-184, 1993.

Mechler, R., Hochrainer, S., Aaheim, A., Salen, H., and Wreford, A.: Modelling economic impacts and adaptation to extreme events: Insights from European case studies, Mitigation and adaptation strategies for global change, 15, 737-762, 2010.

Monteith, J. L. and Moss, C. J.: Climate and the efficiency of crop production in Britain (and Discussion), Philos. T. Roy. Soc., 281, 277-294, 1977.

Ntegeka, V. and Willems, P.: Trends and multidecadal oscillations in rainfall extremes, based on a more than 100 years time series of 10 minutes rainfall intensities at Uccle, Belgium, Water Resour. Res., 44, 15 pp., 2008.

Olesen, J. E., Trnka, M., Kersebaum, K. C., Skjelvåg, A. O., Seguin, B., Peltonen-Saino, P., Rossi, F., Kozyra, J., and Micale, F.: Impacts and adaptation of European crop production systems to climate change, Eur. J. Agron., 34, 96-112, 2011.

Palmer, W.: Meteorological Drought. Research paper no. 45, US Department of Commerce Weather Bureau, available by the NOAA National Climatic Data Center at: http://www.ncdc.noaa. gov/temp-and-precip/drought/docs/palmer.pdf, 58 pp., 1965.

Prasad, P. V. V., Craufurd, P. Q., Summerfield, R. J., and Wheeler, T. R.: Effects of short episodes of heat stress on flower production and fruit-set of groundnut (Arachis hypogaea L.), J. Exp. Bot., $51,777-784,2000 b$.
Reidsma, P., Ewert, F., Oude Lansink, A., and Leemans, R.: Adaptation to climate change and climate variability in European agriculture: The importance of farm level responses, Eur. J. Agron., 32, 91-102, 2010.

RMI (Royal Meteorological Institute): Huidig klimaat van België, Royal Meteorological Institute of Belgium, Brussels, available at: http://www.meteo.be/meteo/view/nl/6042923-Huidig+ klimaat+Belgie.html (last access: 26 January 2012), 2012 (in Dutch).

Rodriguez, D. and Sadras, V. O.: The limit to wheat water use efficiency in eastern Australia, I. Gradients in the radiation environment and atmospheric demand, Aust. J. Agr. Res., 58, 287-302, 2007.

Rizhysky, L., Liang, H., Shuman, J., Shulaev, V., Davletova, S., and Mittler, R.: When defense pathways collide: The response of Arabidopsis to a combination of drought and heat stress, Plant Physiol., 134, 1683-1696, 2004.

Saxton, K. E. and Rawls, W. J.:. Soil Water Characteristic Estimates by Texture and Organic Matter for Hydrologic Solutions, Soil Sci. Soc. Am. J., 70, 1569-1578, 2006.

Schlenkera, W. and Roberts, M. J.: Nonlinear temperature effects indicate severe damages to US crop yields under climate change, Proc. Natl. Acad. Sci., 106, 15594-15598, 2009.

Semenov, M. and Shewry, P. R.: Modelling predicts that heat stress, not drought, will increase vulnerability of wheat in Europe, Nature Scientific Reports, 1, 66, 2011.

Tashiro, T. and Wardlaw, I. F.: A comparison of the effect of hightemperature on grain development in wheat and rice, Ann. Bot., 64, 59-65, 1989.

Tsakiris, G., Pangalou, D., and Vangelis, H.: Regional Drought Assessment based on the Reconnaissance Drought Index (RDI), Water Resour. Manag., 21, 821-833, 2007.

Wand, S. J. E., Midgley, G. F., Jones, M. H., and Curtis, P. S.: Responses of wild $\mathrm{C} 4$ and $\mathrm{C} 3$ grass (Poaceae) species to elevated atmospheric $\mathrm{CO}_{2}$ concentration: a meta-analytic test of current theories and perceptions, Glob. Change Biol., 5, 723-741, 1999.

Witcombe, J. R., Hollington, P. A., Howarth, C. J., Reader, S., and Steele, K. A.: Breeding for abiotic stresses for sustainable agriculture, Philos. T. R. Soc. B, 363, 703-716, 2008. 